\title{
The Validity of Village Head Officer Activities in Managing Village Governance
}

\author{
I Wayan Arthanaya ${ }^{1}$, I Nyoman Sutama ${ }^{2}$, I Pt Gd Seputra ${ }^{3}$ \\ \{arthanaya.wayan@gmail.com ${ }^{1}$ \} \\ Fakultas Hukum Universitas Warmadewa Denpasar-Bali, Indonesia ${ }^{123}$
}

\begin{abstract}
This paper examines the authority to act as well as the validity of the actions of the acting Head of the Village as a substitute for the Village Head who stops or is dismissed as stipulated in the Village Government law. This study is normative legal research with a legislative approach and a conceptual approach to find and find the basis for the arrangement of actions of Acting Village Heads. The results of the study indicate that acting as Village Head as a substitute for the Village Head. Dealing with government affairs requires a legal action in the form of a decision, but there is no regulation regarding that action. Meanwhile, the rule of the Village Head's decision is stipulated in the Minister of Home Affairs Regulation No. 111 In 2014, based on Article 8 of the law concerning the formation of legislation. Contrary, it could be said that to be rolling as Village Chief who can issue a decision, it is valid if it meets formal requirements and material requirements.
\end{abstract}

Keywords: Acting Village Chief, Authority, Validity.

\section{Introduction}

Article 1 paragraph (1) of the 1945 Constitution of the Republic of Indonesia (UUD NRI Th.1945), states: Indonesia is a Unitary State in the form of a Republic, while Article 1 paragraph (3) revealed Indonesia is a legal state. In this regard, the administration of the territory of the Unitary State of the Republic of Indonesia is regulated in Article 18 paragraph 7 of the Constitution of NRI Th.1945, which states: "The structure and procedures for administering regional government are regulated in the law." The governance arrangement referred to is Central Government, Provincial Government, Regency / City Government, and Village Government under the District and City carried out by the Village Government (Village Head) and Village Consultative Body (BPD) assisted by Village Devices. They are given autonomy rights to certain limits as a legal community unit that has the right to regulate and manage the interests of the local community based on their rights of origin and traditional rights. [1]. Article $18 \mathrm{~B}$ paragraph (2) of the Constitution of the Republic of Indonesia Th.1945 states: "The State recognizes and respects customary law units along with their traditional rights as long as they are alive and by the development of the people and principles of the Unitary Republic of Indonesia. Invite ". Based on Article 18 paragraph (7) and Article 18 B paragraph (2), Number Law is established. 6 of 2014 (Law No. 6 of 2014) concerning the Village and its implementing regulations, namely the Implementing Regulation Number. 43 of 2014 (PP No.43 Th 2014), where Article 1 number 1 about General Provisions said that 
"Villages are traditional villages and referred to by other names, in the future referred to as Villages are legal community units that have territorial limits authorized to regulate and managing government affairs. The interests of the local community based on community initiatives, origin rights, and traditional rights that are recognized and respected in the system of government of the Unitary State of the Republic of Indonesia ".

Referring to the Explanation of Law No. 6 the 2014, it was stated that: the merging of the function of the self-governing community with local self-government, it is expected that the customary law community unit which has been part of the village territory has been arranged in such a way as the Desa and Desa Adat. Therefore, in the future Indigenous Villages and Villages can make changes to the face of the Village and the governance of effective governance, implementation of appropriate development, and fostering and empowering communities in the region. The existence of reforms has resulted in a paradigm shift in government administration that is oriented to the concept of good governance from the idea of rule government. According to the good governance paradigm, the government no longer relies on regulations or government alone, but also must involve other elements such as the role of the private sector and community members [2]. In the implementation of the Village Government, the Village Head has a significant part because of his position as an extension of the state that is close to the community and as a community leader. Therefore, it has become his duty, authority, obligation, and responsibility as the foremost person to organize governance to accelerate further the process of achieving the goal of a prosperous and prosperous just society. The Village Head in coordinating the Village Government is responsible to the community, also obliged to submit reports on the implementation of the Village Government at the end of each fiscal year. At the end of each term to the Regent / Mayor; must provide a written statement of government administration to the Village Consultative Body at the end of each fiscal year and supply or disseminate information on government administration in writing to the village community at the end of the fiscal year.

The Village Head can stop or be dismissed, whether due to death, at his request, the end of his term of office and others, or the postponement of the election of the Village Chief, causing the vacant position of the Village Chief. In this regard, the Regent / Mayor can appoint civil servants from the Regency / City Government as acting Village Heads until the Village Head is elected through the Village Conference. Acting Village Chief appointed by the Regent / Mayor can carry out the same duties, authority, rights, and obligations as the Village Head. In the implementation of responsibilities, authority, rights, and obligations Acting Village Chief aris given the power to make a decision, which should not conflict/violate the rules of written law or unwritten legal rules. [3] In connection with the decision issued by Acting Village Chief E.Utrecht stated that in making decisions must pay attention to the provisions contained in the State Law concerning competencies and objectives and State Administrative Law regarding the procedure. [4] Therefore there is a need for analysis and assessment regarding the authority to act as acting Head of the Village in the administration of the Village government, and the actions taken are said to be legitimate.

\section{Methodology}

This study is normative legal research with the legislative and conceptual approach. The licensed material is a primary legal material in the form of legislation, while secondary legal documents through library studies, where the collection of legal articles is carried out using a 
card system arranged in alphabetical order. Furthermore, the data is analyzed using the logic flow of normative legal research through the steps of describing the actual legal content and structures that have been studied. Then systematized to define the hierarchical relationship between the applicable legal rules for the administration of village governance, so that they can be well understood so that they can be used as information in the literature.

\section{Result and Discussion}

\subsection{Village Government}

The diversity of character and type of village does not become a barrier for the founders of the country to make their choice on the composition of the unitary state. Although it is realized that in a unitary country there needs to be homogeneity, but the Unitary State of the Republic of Indonesia (NKRI) continues to recognize and guarantee the existence of legal community units and customary law community units along with their origin and traditional rights. Referring to Article 18 paragraph 7 of the 1945 Constitution of the Republic of Indonesia, the Village Government was integrated into the Regional government structure in the Indonesian government system [5], where Josep Mario Monteiro stated that the Village type had mixed authority, between original autonomy and semi-formal autonomy. It was called a mixture because the aboriginal self-government was recognized by law and was also given the transfer of power from the Regency / City during semi-autonomy because this model of surrendering autonomous regional government affairs to government units under it was unknown in the theory of decentralization. According to the literature of decentralization or regional autonomy, the surrender of government affairs is only from the central government. [1] The authority of the Village in the implementation of the Village Government is the authority in the application of the Village Government, the enforcement of Village development, Village community development, and the empowerment of the Village community based on community initiatives, the origin rights, and customs. The said authority includes authority based on origin rights; village scale local authority; power assigned by the Government, Provincial Government, Regency / City Government and other authorities appointed by the Government, Provincial Government, Regency / City Regional Government by the provisions of the legislation. In the implementation of its authority, it is based on Village Regulations, Joint Regulations of the Village Head, and Village Head Regulations which are the types of regulations in the Village. Besides the authority mentioned above, Law No. 6 of 2014 also requires that the implementation of the Village Government be carried out by legal certainty; the principle of governance; public interest; transparency; proportionality; professionalism; accountability; effectiveness; local security; diversity and participatory. All of the authority exercised by the Village Head in the framework of the implementation of Village governance is based on the power of attribution, delegation and mandate authority. 


\subsection{Village Chief}

The position of the Village Head is vacant, partly because the Village Head stops or is dismissed by the official who appoints him. Whereas the location of the Village Head must not be empty for too long because besides influencing the smooth running of government and development, it will also have unfavorable consequences for calm and order in the Village. Dismissal of the Village Head is regulated in Article 54 PP No. 43 of 2014, Article 54 paragraph (1) states: The Village Head stops because a. die; b. Own request; c. Dismissed. Article 54 paragraph (2) declared that Village Head is dismissed as referred to in paragraph (1) letter $\mathrm{c}$, because of a. Ends of his term of office; b.not able to carry out tasks continuously or permanently unable to attend for 6 (six) months; c. No longer qualifies as Village Head; d. Violates the prohibition as Village Head; e. there is a change in the status of the Village to Kelurahan; f. does not carry out obligations as Village Head, or g. It is stated as a convict based on a court decision that has permanent legal force. Whereas paragraph (3) says: if the Village Head stops as referred to in paragraph (1), the Village Consultative Body reports to the Regent / Walokota through the Camat or other designation. To avoid the vacant position of the Village Head, the Regent / Mayor can appoint civil servants from the Regional Government as acting Village Heads who have the same duties, authority, rights, and obligations as the Village Head until the new Village Chief is elected through the Village Conference. Provisions governing the filling in vacant positions of the Village Chief are: Article 55 and Article 56 PP No. 43 of 2014. Article 55 stated that if the remaining term of office of the Village Chief stops no more than 1 (one) year due to dismissal as referred to in Article 54 paragraph (1) letters a and b. Paragraph (2) letter b, c, d, f, and letter g, the Regent / Mayor appoints civil servants from the Regency / City Regional Government as Acting Village Heads until the new Village Chief is elected. Whereas Article 56 states: in the remaining term of office of the Village Chief who has stopped more than 1 (one) year because he was dismissed as referred to in Article 54 paragraph (1) letter and b and paragraph (2) letters b, c, d, f, and letters g, the Regent / Mayor appoints civil servants from the Regency / City Regional Government as acting Village Heads until the new Village Chief is elected through the Village Consultation. Based on the provisions of Article 58 paragraph (2) PP No. 43 of 2014 states: Civil servants appointed as Acting Village Heads carry out duties, authorities, and obligations and obtain the same rights as the Village Head, it can be said that when viewed from the legal side between the Village Head and Acting Village Chief, the legitimacy is different.

\subsection{Authority of Acting Village Chief}

The Village Head as a government official in the Village can take legal action in the form of a Village Regulation jointly made with the Village Consultative Body, Village Head Regulation and Village Head Decree. This is based on the provisions of Article 8 of Law Number 12 the Year 2011 concerning Establishment of legislation. Where Article 8 paragraph 1 states: Types of legislation other than as intended in Article 7 paragraph (1) include regulations stipulated by the People's Consultative Assembly (MPR), People's Representative Council (DPR), Regional Representative Council (DPD), the Supreme Court (MA), the Constitutional Court (MK), the Supreme Audit Agency (BPK), the Judicial Commission, Bank Indonesia, Ministers, Agencies, Institutions, or Commissions that are formed by law or by law- legislation, Provincial Regional Representatives Council (DPRD), Governor, District / 
City, District / Wal / Regional People's Representative Council Ikota, Village Head or equivalent. Whereas Article 8 paragraph 2 states: Legislation, as referred to in Article 7 paragraph (1), is recognized and has binding legal force insofar as it is ordered by higher legislation or established based on authority. From the sound of Article 8 paragraph (1) and (2), then through the Minister of Home Affairs Regulation Number. 111 of 2014 concerning Technical Guidelines for Village Regulations, Article 31 states: The Village Head can determine the Decree of the Village Head for the implementation of village regulations, higher legislation and in the framework of implementing stipulating Village authorities. Based on this, because of the role of Village Chief as a substitute for the Village Head who has the same duties, authority, rights, and obligations. As Contrary, Village Head has the power to take legal action in the form of a decree that describes the kind of stipulation which is individual, final and concrete, but only applies to the environment of the Village area.

\subsection{The validity of Acting Acting Village Chief}

Acting Village Chief as a government official in the Village in administering government affairs can issue a decision, but for accuracy in decision making, the decision must fulfill the character as an arrangement of a government official (in the State Administrative Law is called the Decision of the State Administration). The principle of accuracy in issuing decisions is the validity of choices, then the decision (beschikking) must fulfill the formal requirements. Procedure to decide starts from stipulation; notification of the judgment of the person concerned as well as material conditions. The institution which resolves should be authorized according to his position; stipulation must be made in the absence of juridical deficiencies in the formation of willingness when making requirements on the officials, and determination must go to the right target. This aims to avoid the existence of claims from the recipient of the decision.

\section{Conclusion}

Village Head Officials as a substitute for the Village Head because of stopping or being dismissed for specific reasons appointed by the Regent / Mayor of the regional government civil servants. They have the authority to act in the form of stipulating decision making as the elaboration of Village Regulations, Village Head Regulations, and legislation higher law and in the framework of the implementation of village authority which is of a stipulating nature Acting. Village Head is said to be valid as a Decision if it can fulfill formal requirements. Procedure to make a determination starts from stipulation; notification to the person concerned and the material conditions are: the agency making the commitment must be authorized according to his position; requirement must be made in the absence of juridical deficiencies in the formation of willingness when making stipulations on the officials, and determination must go to the right target. This aims to avoid the existence of claims from the recipient of the decision.

\section{Acknowledgment}

The author would like to say to all those who have helped and contributed to the writing of this article, both in terms of funding and critical ideas. Hopefully this paper can be useful 
both theoretically and practically, as well as to increase the development of legal knowledge for the community.

\section{References}

[1] Moneiro, J. M.: Pemehaman Dasar Hukum Pemerintahan Daerah, Konsepsi, Kewenangan, Desa, Produk Desa, dan Peraturan Daerah. Pustaka Yustisia, Yogyakarta (2016)

[2] Ilmar, A.: Hukum Tata Pemerintahan. Prenadamedia Group, Jakarta (2008)

[3] Atmosudirdjo, P.: Hukum Administrasi Negara. Ghalia Indonesia, Jakarta (1988)

[4] Huda, N.: Hukum Pemerintahan Desa (Dalam Konstitusi Indonesia Sejak Kemerdekaan Hingga Era Reformasi). Setara Press, Malang (2015)

[5] Utrecht. E.: Pengantar Hukum Administrasi Indonesia. Pustaka Tinta Mas, Surabaya (1986) 